\title{
Rotaxane-Based Photosensitizers
}

\section{A [5]Rotaxane-Based Photosensitizer for Photodynamic Therapy}

\author{
Melis Özkan, ${ }^{[a]}$ Yağmur Keser, ${ }^{[a]}$ Seyed Ehsan Hadi, ${ }^{[a]}$ and Dönüs Tuncel ${ }^{*[a, b]}$
}

\begin{abstract}
A [5]rotaxane was synthesized through a catalytically self-threading reaction in which CB6 serves as a macrocycle and acts as a catalyst for the 1,3-dipolar cycloaddition reaction between the alkyne substituted porphyrin core and azide functionalized stopper groups by forming triazole. Application of this rotaxane as a photosensitizer in photodynamic therapy against cancer cells and in bacteria inactivation have also been demonstrated. This photosensitizer has an excellent water solubility and remains stable in biological media at physiological $\mathrm{pH}$ (7.4) for prolonged times. It has the ability to generate sin-
\end{abstract}

glet oxygen efficiently; while it shows no dark cytotoxicity up to $300 \mu \mathrm{m}$ to the MCF7 cancer cell line, it is photocytotoxic even at $2 \mu \mathrm{m}$ and reduces the cell viability to around $70 \%$ when exposed to white light. It also displays light-triggered biocidal activity both against gram-negative bacteria (Escherichia coli, E. coli) and gram-positive bacteria (Bacillus subtilis). Upon white light irradiation for $1 \mathrm{~min}$ with a flux of $22 \mathrm{~mW} / \mathrm{cm}^{2}$ of E. coli suspension incubated with [5]rotaxane $(3.5 \mu \mathrm{M})$, a killing efficiency of $96 \%$ is achieved, whereas in the dark the effect is recorded as only around $9 \%$.

\section{Introduction}

Rotaxanes are a fascinating class of compounds with many interesting properties and potential applications. ${ }^{[1,2]}$ They are composed of an axle-like molecule which is threaded by a macrocycle and terminated with bulky stopper groups that prevent a macrocycle to slip off from the axle. These mechanically interlocked supramolecules can be synthesized using a number of different macrocycles including crown ethers, cyclophanes, calixarenes, cyclodextrins and cucurbiturils $(\mathrm{CBs}) .{ }^{\left[{ }^{-5]}\right.}$ The degree of threading and the nature of the macrocycle can significantly affect the physical and chemical properties of axle molecule.

Among those macrocycles, $C B$ is highly attractive as it offers a very rich host-guest chemistry due to its two identical hydrophilic portals and a hydrophobic cavity. It binds with guest through ion-dipole interactions as well as hydrophobic effect. ${ }^{[5,6]}$ Acid catalyzed condensation of glycoluril with formaldehyde forms CB-homologues in various sizes. The number of glycol units are denoted by $n$ and for most common CB homologues, $n$ can be $5,6,7,8 .{ }^{[6]}$ Among them CB6 has very important feature that is its ability to catalyze 1,3-dipolar cycloaddition between properly substituted alkyne and azide substrates by forming 1,4-disubstituted triazoles. This feature was extensively explored in the synthesis of rotaxanes and polyrotaxanes. ${ }^{[5-7]}$

[a] Institute of Materials Science and Nanotechnology,

National Nanotechnology Research Center (UNAM), Bilkent University, 06800 Ankara, Turkey

[b] Department of Chemistry, Bilkent University, 06800 Ankara, Turkey

E-mail:dtuncel@fen.bilkent.edu.tr http://www.fen.bilkent.edu.tr/ dtuncel/index.html

Supporting information and $O R C I D(s)$ from the author(s) for this article are available on the WWW under https://doi.org/10.1002/ejoc.201900278.
In this paper, we have revisited our earlier work which was on the synthesis of novel CB6-based rotaxane via 1,3-dipolar cycloaddition catalyzed by $\mathrm{CB} 6 .{ }^{[7]}$ Resulting rotaxane is composed of a tetraphenyl porphyrin core which is surrounded by four CB6s and it is called [5]Rotaxane. ${ }^{[8]}$ Tetraphenyl porphyrin has been selected because porphyrin derivatives are very appealing as a photosensitizer due to their absorption in the visible range of the electromagnetic spectrum, long-lived triplet excited state, high molar extinction coefficient and their ability to generate singlet oxygen when they are irradiated with visible light. ${ }^{[9]}$

The light, photosensitizer, and molecular oxygen are main components to generate reactive oxygen species (ROS) including singlet oxygen that are mainly responsible for the photodynamic therapies against cancer cells or bacteria inactivation. ${ }^{[0 a]}$ Photodynamic antimicrobial chemotherapy (PACT) can be considered as a very efficient approach in killing pathogens with resistance to antibiotics ${ }^{[10]}$ as the antibiotic resistance of microorganisms has become a serious global challenge. ${ }^{[11]}$ An ideal photosensitizer to be used in the photodynamic therapy should have good water solubility, be stable in the biological milieu and should not exhibit dark cytoxicity. ${ }^{[10,11]}$ Although attaching hydrophilic and ionic groups to the meso-positions of porphyrin core improve the water solubility, aggregate formation caused by $\pi-\pi$ interactions and hydrophobic effect is still an issue that should be tackled. ${ }^{[10,12]}$ However, ionic groups attached to porphyrin derivatives as solubilizers can also cause dark toxicity. Recently, supramolecules have been employed as a photosensitizer in $\mathrm{PACT}^{[13-16]}$ especially, the inclusion complexes of cationic porphyrin derivatives with $C B$ homologues seem to be promising as they show limited dark cytotoxicity. ${ }^{[16]}$ For example, Zang et al. reported a highly efficient supramolecular photosensitizer based on the inclusion complex of CB7 with cationic porphyrin decorated by naphthalene guests. ${ }^{[16 a]}$ They have demonstrated that inclusion complex formation signifi- 
cantly reduces the dark toxicity but the complex is highly toxic when irradiated with light. However, to the best of our knowledge, rotaxane-based photosensitizers have not been reported to date. Rotaxane-based photosensitizer is expected to be more stable in a variety biological media than the pseudorotaxanebased photosensitizers. This is especially important for in vivo applications because biological media contain a number of different competitive guests for CBs that will cause a premature disassembly of pseudorotaxane before reaching and accumulating in the target. This, in turn, can increase the dark cytotoxicity.

Our porphyrin-cored [5]rotaxane confers the requirements of an ideal photosensitizer as it has an excellent solubility in water and highly stable in biological media (PBS, at $\mathrm{pH} 7.4$, DMEM). Also, due to the presence of bulky $C B$ units which limits the interaction of porphyrin, no aggregate formation was observed. Moreover, it does not show any dark toxicity although it contains cationic ammonium ions which are disguised by $C B$ units by forming complexes with carbonyl groups.

\section{Results and Discussion}

[5]Rotaxane was synthesized as shown in Scheme 1 by a method similar to our previously reported procedure. ${ }^{[8]}$ The precursor Porphyrin 1 (1 equiv.) was dissolved in water, CB6 (4.4 equiv.) and tert-butyl azidoethylammonium chloride (4.4 equiv.) was added to it. The reaction mixture was stirred at room temperature for 24 hours. A clear greenish solution was obtained which was poured into dialysis tube and dialyzed overnight against water to remove excess CB6 and unreacted monomers. The resulting solution was freeze dried to obtain burgundy coloured powders in $87 \%$ yield. [5]Rotaxane was characterized by spectroscopic techniques $\left({ }^{1} \mathrm{H},{ }^{13} \mathrm{C}\right.$ NMR and FT-IR) to elucidate its structure and its molecular weight was determined by ESI-mass spectrometry (Supporting Information, Figure S1-S4). [5]Rotaxane dissolves well in water and PBS buffer ( $\mathrm{pH}$ 7.4), remains stable over long time period.

Once we authenticated the structure of the desired [5]rotaxane, we set out to investigate its photophysical properties and its ability as a photosensitizer. Figure 1 shows the UV/Vis absorption and fluorescence spectra of [5]rotaxane at various concentration in water. A sharp Soret band $\left(\lambda_{\max }\right.$ at $\left.415 \mathrm{~nm}\right)$ and four weak Q-bands ( $\lambda_{\text {abs }}$ at $517,553,582$, and $636 \mathrm{~nm}$ ) in the spectrum indicating the typical absorption peaks of free base porphyrins. It is clearly seen that the presence of bulky CB6 units prevents the interactions between porphyrin units and as a result, an aggregate formation is prevented and the photophysical properties of porphyrin core is preserved in aqueous media. The excitation of [5] rotaxane in water at $415 \mathrm{~nm}$ resulted fluorescence emission above $600 \mathrm{~nm}$ as characteristic of porphyrin with two vibrational bands at 646 and $707 \mathrm{~nm}$. (Figure 1). While the concentration of [5]rotaxane increases, its emission intensity decreases as can be seen from Figure 1, probably due to self-quenching caused by short-range interactions between the fluorophores. Fluorescence quantum yield and life time are measured as $10 \%$ and $7.5 \mathrm{~ns}$, respectively in water $(5 \mu \mathrm{M})$.

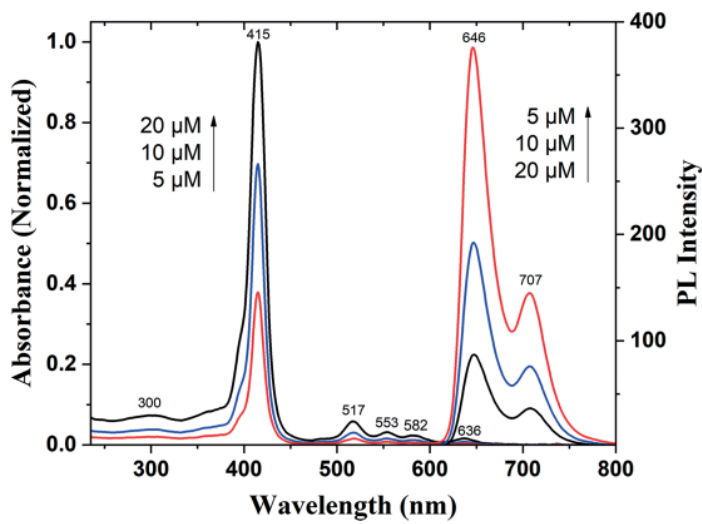

Figure 1. UV/Vis absorption and fluorescence spectra of [5]rotaxane in water at various concentrations.

Light triggered reactive oxygen species (ROS) generation ability of [5]rotaxane can be investigated by using a probe, 2,7-dichlorofluorescein diacetate (DCFH-DA). ${ }^{[16,17]}$ 2,7-dichlorofluorescin (DCFH) which can be obtained by a hydrolysis of DCFH-DA in an alkaline medium is very sensitive to ROS and could quickly turn into highly fluorescent 2,7-dichlorofluorescein (DCF) (Scheme 2) leading a significant increase in the fluorescence intensity around $524 \mathrm{~nm}$.

As shown in Figure 2a, ROS generation ability of [5]rotaxane was evaluated upon exposure to white light with a light intensity of $1 \mathrm{~mW} / \mathrm{cm}^{2}$. When DCFH was irradiated in the absence of [5]rotaxane, very weak emission band at $524 \mathrm{~nm}$ was observed due to autooxidation of DCFH to DCF. Upon addition of
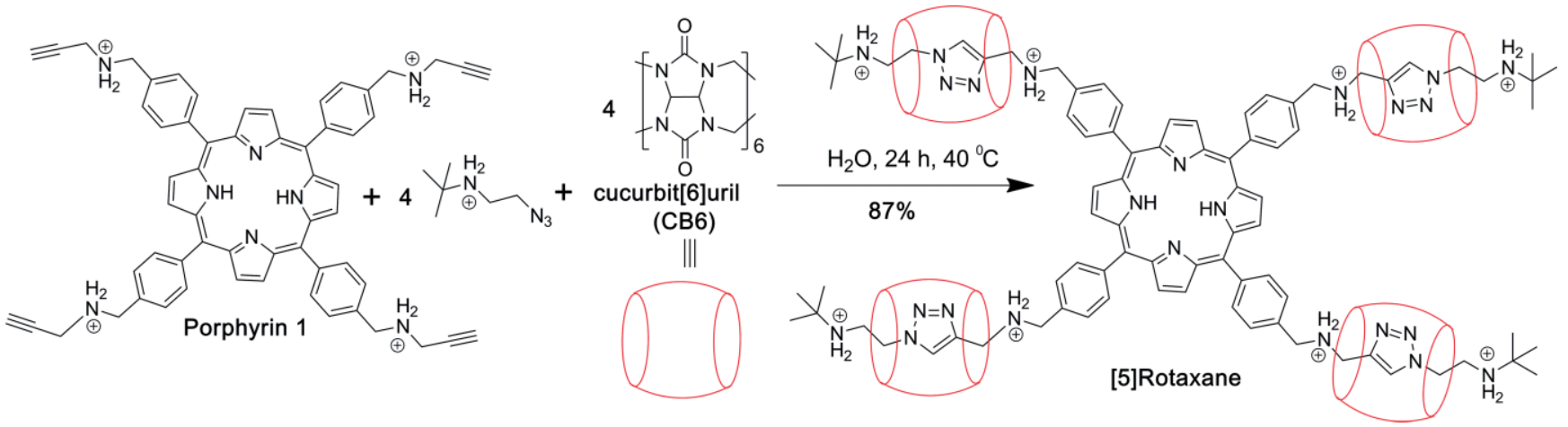


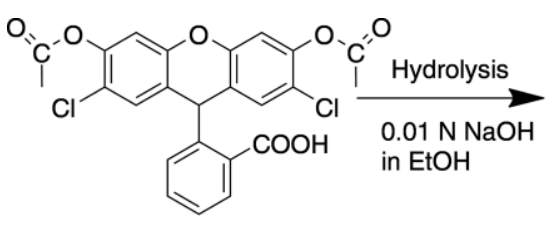

DCFH-DA

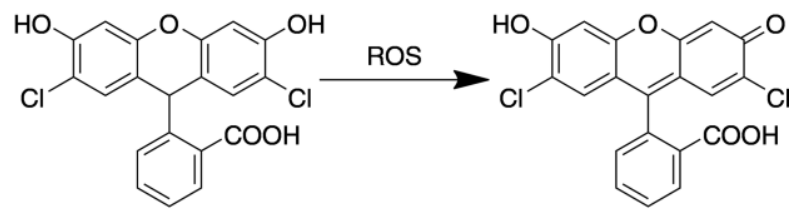

DCFH
DCF

Scheme 2. Molecular structures of 2,7.dichlorofluorescin diacetate (DCFH-DA), 2,7-dichlorofluorescin (DCFH) and the reaction of DCFH with ROS to produce highly fluorescent 2,7-dichlorofluorescein (DCF).

(a)

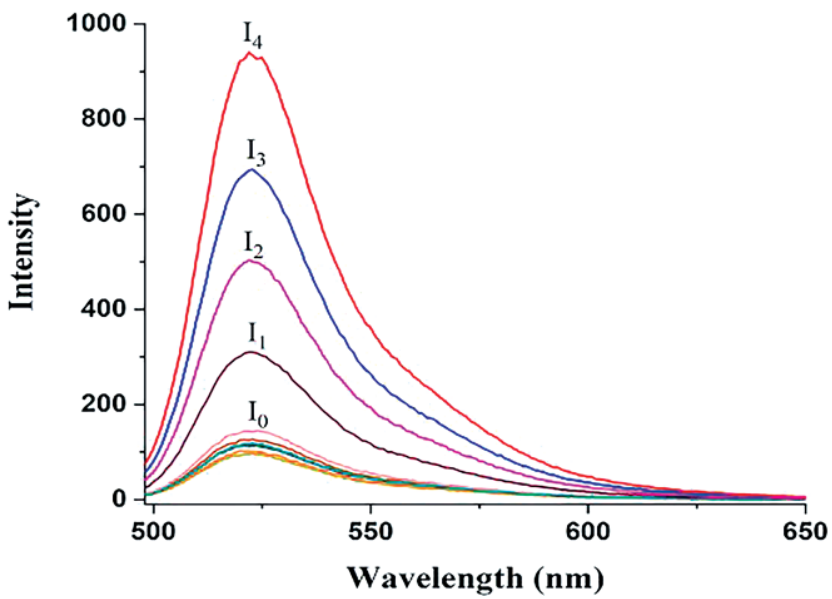

(b)

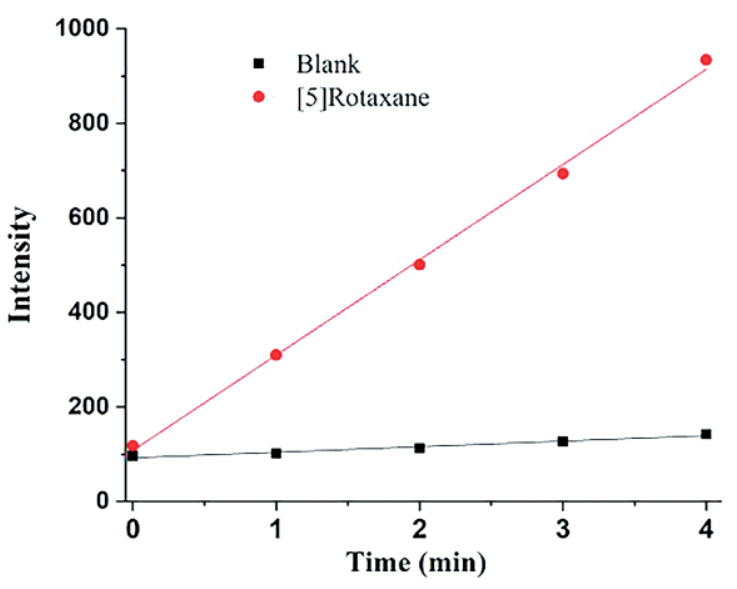

Figure 2. (a) Fluorescence intensity of DCF at $524 \mathrm{~nm}$ as blank and in the presence of [5]rotaxane (5 $\mu \mathrm{M})$ under continuous white light illumination. $\mathrm{I}_{0}, \mathrm{I}_{1}, \mathrm{I}_{2}$, $\mathrm{I}_{3}, \mathrm{I}_{4}$ correspond to blank and white light irradiated duration for 1, 2, 3, 4 minutes measurements, respectively. (b) Time response curve of DCFH oxidation in the presence of [5]rotaxane and without [5]rotaxane $\left(R^{2}=0.986\right.$ for blank, $R^{2}=0.9976$ in the presence of [5]rotaxane).

[5]rotaxane and before light irradiation, the intensity of peak at 524 did not change much. However, with exposure to light and the peak intensity increased significantly and continue to rise gradually over time as shown in Figure $2 \mathrm{a}$. These results indicate that [5]rotaxane has a remarkable light-triggered ROS generation ability and even under a relatively low light intensity of white light with broad excitation wavelengths, ROS can be generated efficiently.

\section{Investigation of Cytotoxicity and Phototoxicity on Gram-Negative Bacteria, Escherichia coli (E. coli), and Gram-Positive Bacteria, Bacillus subtilis}

After finding out that [5]rotaxane has ability to generate singlet oxygen efficiently, we investigated its light-triggered biocidal activity. For this purpose E. coli, a Gram-negative bacteria, which is responsible for half of the infections was selected as a model and their interactions with [5]rotaxane were investigated. Bacterial survival experiments were carried out using various concentrations of [5]rotaxane in the dark and upon exposure to white light for $1 \mathrm{~min}$. with flux of $22 \mathrm{~mW} / \mathrm{cm}^{2}$ by a surface plating method $^{[18]}$ (Figure $3 c-f$ ). Colony counting showed that the killing efficiency upon irradiation of $E$. coli suspension incubated with [5]rotaxane (3.5 $\mu \mathrm{m})$ was $96 \%$, whereas the killing efficiencies in the dark is only around $9 \%$ (Figure 3b). Studies of the effect of [5]rotaxane concentrations on killing efficiency toward
E. coli under irradiation showed that the killing efficiency enhanced with increasing concentration of [5]rotaxane and reaches a plateau after $3.5 \mu \mathrm{M}$ (Figure S6-S8).

We have also investigated the antibacterial activity of Porphyrin 1, which does not contain CB6, toward E. coli in the dark and under light keeping similar conditions (concentration, light intensity, and exposure time) used for [5]rotaxane to find out the effect of CB6. Porphyrin 1 showed biocidal activities around $60 \%$ and $70 \%$, in the dark and under light, respectively (Figure S12 and S13). High dark toxicity of Porphyrin 1 compared to [5]rotaxane can be attributed to strong electrostatic interactions between the ammonium groups with bacteria cell walls and insertion of the hydrophobic part of the porphyrin monomer through hydrophobic interactions. In [5]rotaxane, ammonium groups co-ordinate with the carbonyl portals of CB6 and interact with bacteria cell walls less strongly. Additionally, another drawback of Porphyrin $\mathbf{1}$ is that it forms aggregates in PBS over time.

The light-triggered antibacterial effect of [5]rotaxane against the Gram-positive bacteria ( $B$. subtilis) was also investigated under the same conditions (concentration, light intensity, and exposure time) used for E. coli. While only around $7 \%$ of bacteria survived in the dark, almost $100 \%$ of the bacteria were inactivated under light (Fig. S14, S15). These findings suggest that these nanoparticles can be used as a broad-spectrum antibacterial agent. 
(a)

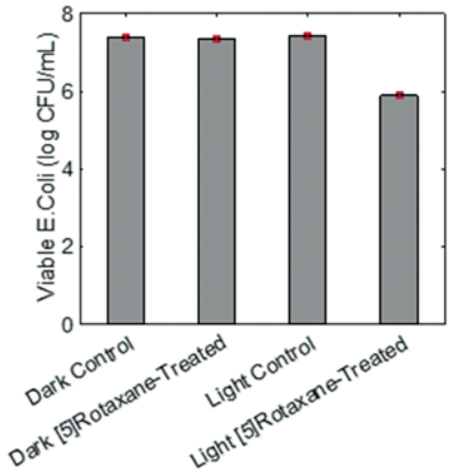

(b)

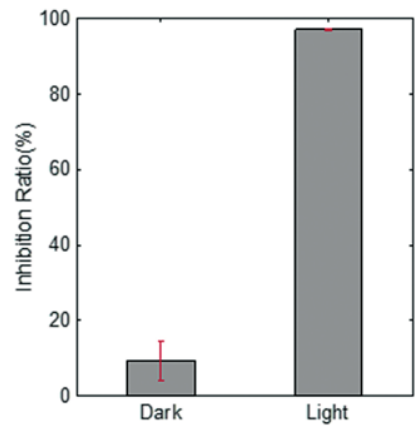

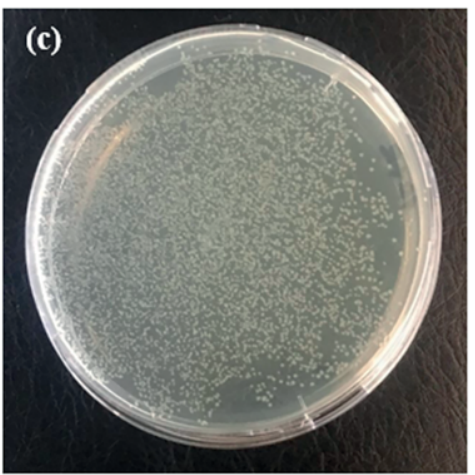
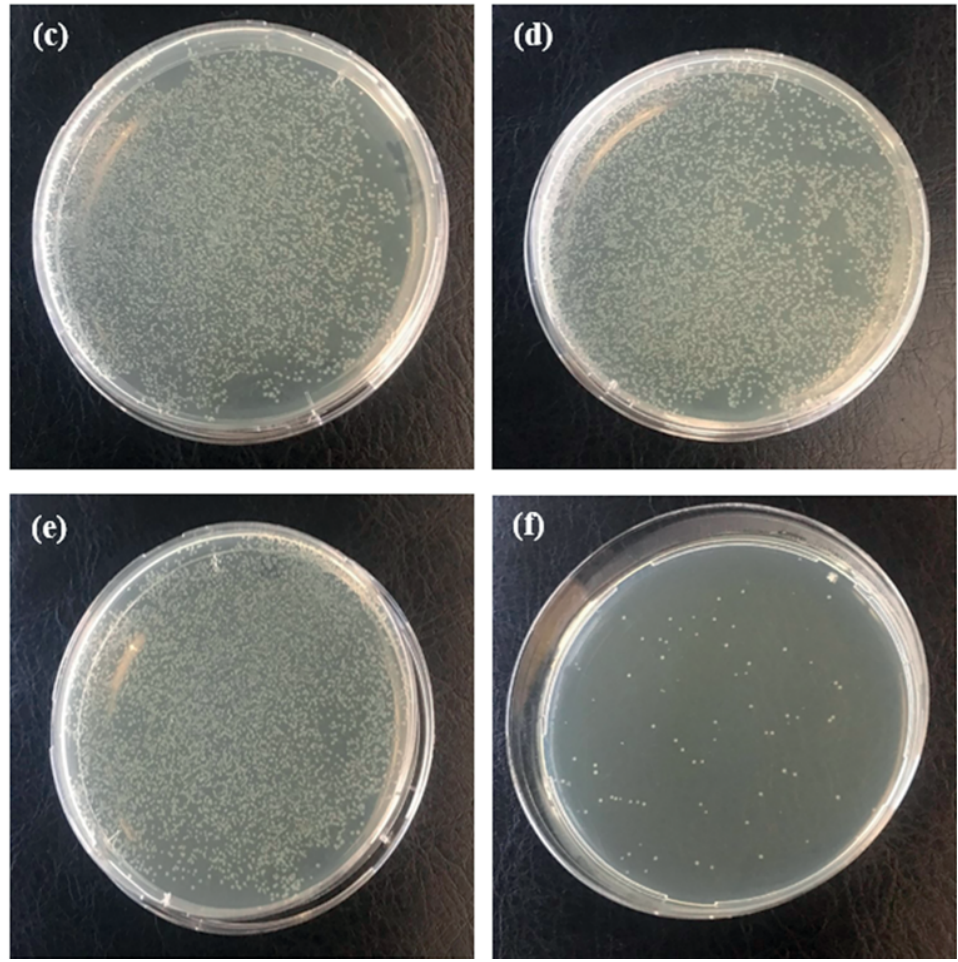

Figure 3. (a), (b) Biocidal activities of [5]rotaxane toward $E$. coli in the dark and under photo-irradiation. The values represent the mean \pm standard deviation (SD) of six separate experiments. Error bars represent SD of data from six separate measurements. Plate photographs for E. coli on YTD agar plate treated (c) without photosensitizer in the dark, (d) with photosensitizer in the dark, (e) without photosensitizer under photo-irradiation (22 mW/cm ${ }^{2}$ white light, 1 min.), (f) with photosensitizer under photo-irradiation $\left(22 \mathrm{~mW} / \mathrm{cm}^{2}\right.$ white light, $\left.1 \mathrm{~min}\right)$.

\section{Photosensitizer and Bacteria Interactions Investigated by Scanning Electron Microscopy (SEM)}

SEM is a powerful method to investigate the morphology of bacteria interaction with a photosensitizer. We took the SEM images of bacteria ( $E$. coli) which are treated with [5]rotaxane at a MIC $(3.5 \mu \mathrm{M})$ in the dark and under light. Figure $4 \mathrm{~b}$ shows the SEM image of $E$. coli treated with [5]rotaxane in the dark along with its control group (Figure $4 \mathrm{a}$ ). As can be seen from the images, in the dark most of the bacteria are in good shape and not affected by the photosensitizer by preserving their smooth surfaces. However, in the case of bacteria treated with light exposure, SEM images showed that the surface of $E$. coli bacteria treated with [5]rotaxane (Figure 4d) were collapsed, fused and their membranes were ruptured in comparison with that of control group in the absence of [5]rotaxane (Figure 4c).

The result confirmed that [5]rotaxane could destroy the bacterial outer membrane upon light irradiation but not in the dark. These observations also are in line with antibacterial experiments.

Although the axle molecule is cationic with many ammonium ions that are known to cause dark toxicity because of the strong electrostatic interaction between positive charges and bacteria, CB6s disguise them by forming ion-dipole complexes and this, in turn, decreases the cytotoxicity. However, [5]rotaxane can still interact with bacteria albeit with weaker binding and accumulates on the surfaces, upon light exposure ROS are generated and destroy the membrane of the bacteria as can also be seen in the SEM images.
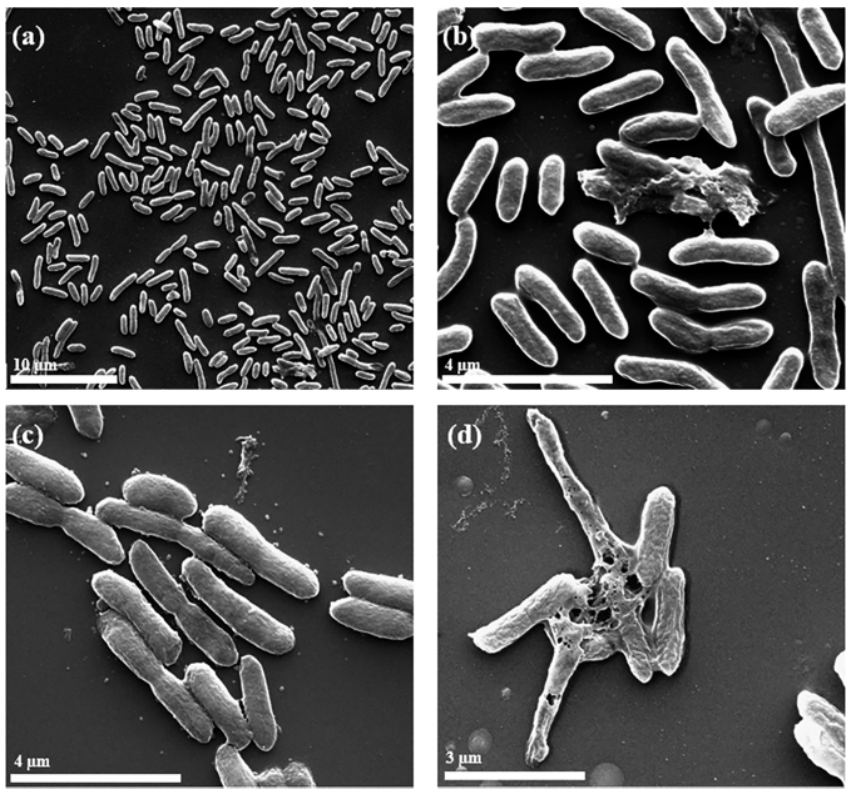

Figure 4. SEM images of E. coli. (a) without photosensitizer in the dark, (b) with photosensitizer $(3.5 \mu \mathrm{M})$ in the dark, (c) without photosensitizer under photo-irradiation ( $22 \mathrm{~mW} / \mathrm{cm}^{2}$ white light, $1 \mathrm{~min}$.), (d) with photosensitizer $(3.5 \mu \mathrm{m})$ under photo-irradiation $\left(22 \mathrm{~mW} / \mathrm{cm}^{2}\right.$ white light, $1 \mathrm{~min}$ ).

Binding of [5]rotaxane with E. coli was also supported by $\zeta$-potential measurements. When E. coli were mixed with [5]rotaxane, positive $\zeta$-potential shifts were observed from 
(a)

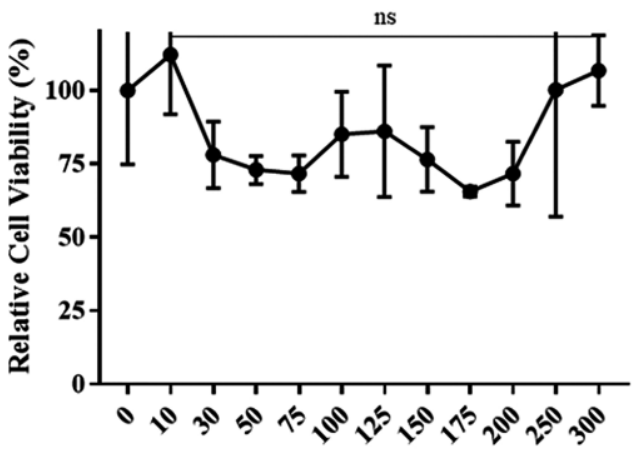

[5]Rotaxane concentrations $(\mu M)$ (b)

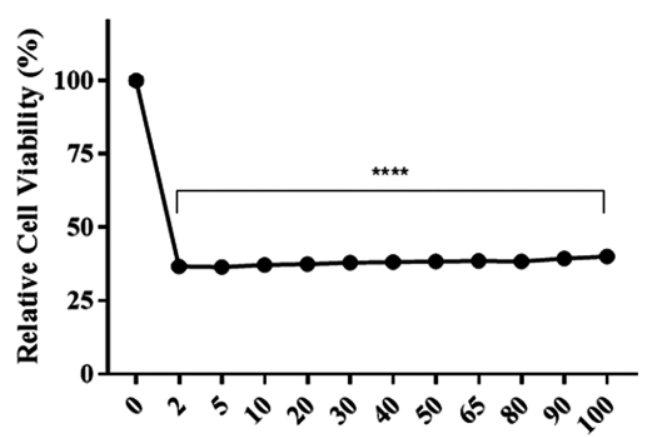

[5]Rotaxane concentrations $(\mu \mathrm{M})$

Figure 5. Relative cell viability (\%) measurements obtained from MTT analysis at the given concentrations ( $\mu \mathrm{M})$ of [5]rotaxane treatments upon normalization with DMEM control group in MCF7 cells $(a)$ in the dark $(P=0.0653)$ and (b) upon white light irradiation $\left(10\right.$ min, $\left.20 \mathrm{~mW} / \mathrm{cm}^{2}\right)(P<0,0001)$. Differences in MTT relative cell viability (normalized to DMEM control group) were analyzed for each dose in each cell line separately using one-way ANOVAs followed by multiple comparisons (Tukey's at $\alpha=0.05$; Graphpad). ${ }^{* * * *} \mathrm{P}<0.0001$; ns: non-significant.

-45.7 to $-33.3 \mathrm{mV}$ and from -50.3 to $-22.9 \mathrm{mV}$, in the dark and under light, respectively (Figure S16).

\section{Investigation of Cytotoxicity and Photocytotoxicity on the MCF7 Cell}

MTT assay was employed to determine the cytotoxicity of [5]rotaxane on mammalian cells in-vitro. For this purpose, MCF7 was chosen as the representative breast cancer cell line and treated with different concentrations of [5]rotaxane in the dark and under white light exposure. On the basis of dark cytotoxicity test, various concentrations of [5]rotaxane (10-300 $\mu \mathrm{M})$ together with DMEM control group were used to observe cytotoxicity of [5]rotaxane. [5]rotaxane did not show any significant cytotoxic effect on MCF7 cells between control DMEM group and any of the concentrations used $(P=0.0653)$ and had a high cell survival rates. This finding supported the safety of this supramolecular photosensitizer on mammalian cells in the dark even at a concentration ( $300 \mu \mathrm{m})$ higher than that used in antibacterial experiments (Figure 5).

We also determined the photodynamic activity of [5]rotaxane on cell viability upon light irradiation, MCF7 cells were treated with white light $\left(20 \mathrm{~mW} / \mathrm{cm}^{2}\right)$ with different exposure times $(5,10$ and $15 \mathrm{~min}$ ) and different concentrations of [5]rotaxane (2-100 $\mu \mathrm{M})$. In contrast, MCF7 cells exhibited significant reductions in relative cell viability after light irradiation. As shown in Figure 5, significant reduction in cell viability was observed at the minimum concentration of [5] rotaxane $(2 \mu \mathrm{M})$ even after $5 \mathrm{~min}$ of light exposure when compared with the DMEM control group $(\mathrm{P}<0.0001)$ (Supporting Information, Figure S9). Moreover, while the light exposure time and concentration of [5]rotaxane was increasing, the rate of decrease on cell viability did not change and remained around $70 \%$ of the DMEM control group at all concentrations including the maximum (100 $\mu \mathrm{M})$ (Figure 5, Figure S9). These results demonstrated that white light efficiently activated [5]rotaxane, hence, reduced the cell viability even at low concentrations with the same rate of reduction observed at high concentrations. Remarkable cell viability inhibition in treatment groups indicated that the potential superiority of anti-tumorigenic activity under light. Thus, the use of [5]rotaxane under light provides a potentially safe strategy for solving the problem of high cytotoxicity which may cause unnecessary side effects. We concluded that [5]rotaxane photosensitizer showed a relatively less toxicity in the dark, whereas it exhibited a high cytotoxic efficiency under light irradiation even at low concentrations.

\section{Conclusions}

[5]Rotaxane having a photoactive axle was synthesized, and its use as an efficient photosensitizer has been demonstrated in the photodynamic therapy. This rotaxane has an excellent water solubility with an ability to generate ROS under light. It exhibits no dark cytotoxicity towards the pathogens (both gram-negative bacteria, E. coli and gram-positive bacteria, B. subtilis) and the mammalian cells (breast cancer cell line, MCF7) even at high concentration (up to $0.3 \mathrm{~mm}$ ). However, it is highly cytotoxic even very low concentration $(2 \mu \mathrm{M})$ under white light with relatively low fluence and short exposure time towards both $E$. coli and $B$. subtilis as well as MCF7 cell line. The results show that [5]rotaxane is a remarkable photosensitizer and its use under light provides a potentially safe strategy for solving the problem of high cytotoxicity, which may cause unnecessary side effects. Moreover, owing to its negligible dark cytotoxicity, it can be used as a therapeutic agent in the light-triggered antibacterial and anticancer therapies.

\section{Experimental Section}

Materials and Measurements: All chemicals used in the syntheses were of analytical grade and were obtained from Sigma-Aldrich and were used as received. Milli-Q water $\left(18.2 \mathrm{M} \Omega \mathrm{cm}\right.$ at $\left.25^{\circ} \mathrm{C}\right)$ was used when needed. Solvents were dried and distilled before used and all reactions were performed under air unless otherwise stated. Thin layer chromatography was performed on $\mathrm{SiO}_{2} 60 \mathrm{~F}-254$ plates and flash column chromatography was carried out using $\mathrm{SiO}_{2} 60$ 
(particle size $0.040-0.055 \mathrm{~mm}, 230-400$ mesh). NMR spectra $\left({ }^{1} \mathrm{H}\right.$, at $400 \mathrm{MHz}$ and ${ }^{13} \mathrm{C}$ at $100 \mathrm{MHz}$ ) were recorded on a Bruker DPX-400 spectrometer in $\mathrm{D}_{2} \mathrm{O}$ solvent and TMS ( $\left.\delta=0.00 \mathrm{ppm}\right)$ as an internal standard. Chemical shifts were reported as $\delta$ values in ppm as referenced to TMS. FT-IR spectra were recorded by Bruker Alpha-II Platinum ATR FT-IR spectrometer. The mass spectra were obtained with Agilent 6224 High Resolution Mass Time-of-Flight (TOF) LC/MS with Electrospray lonization method. UV/Vis absorption spectra were recorded on a UV/Vis spectrophotometer (Cary UV/Vis) with $1 \mathrm{~cm}$ path length quartz cuvettes in the spectral range of $300-800 \mathrm{~nm}$. Emission spectra were recorded on a fluorescence spectrophotometer (Cary Eclipse Fluorescent spectrophotometer). The quantum yields of fluorescence of the compounds were determined using integrated sphere method. Optical density at $600 \mathrm{~nm}\left(\mathrm{OD}_{600}\right)$ of bacteria and the absorbance for MTT analysis (at $570 \mathrm{~nm}$ ) were measured by SpectraMax M5 multi-detection microplate reader system. Samples for Scanning Electron Microscope (SEM) were dried with Autosamdri-934 Critical Point Dryer (Cleanroom), Tousimis. SEM characterization was conducted on FEl Quanta 200F, Thermo Fisher Scientific.

Synthesis of [5]Rotaxane: ${ }^{[8]}$ To the solution of porphyrin 1 (50 mg, $0.049 \mathrm{mmol}$ ) in DI water (5 mL), CB6 (214 mg, $0.215 \mathrm{mmol}$ ) was added. The resulting mixture was stirred for 1 hour to dissolve $C B$ and a green solution was obtained. After adding tert-butylazidoethylamine ( $38.3 \mathrm{mg}, 0.215 \mathrm{mmol}$ ), the mixture was stirred at room temperature for 24 hours. After the completion of reaction, the reaction mixture was cooled to room temperature and poured into a dialysis membrane (regenerated cellulose, MW cut-off $12 \mathrm{kDa}$ ) and dialyzed against water for 24 hours to remove excess CB and monomers. Dialysate was freeze-dried to obtain a fluffy burgundy-colored powders. Yield: $245 \mathrm{mg}(87 \%)$. UV/Vis $\left(\mathrm{H}_{2} \mathrm{O}\right): \lambda_{\max }: 415 \mathrm{~nm}$ $\left(35 \times 10^{4}\right), 517\left(14 \times 10^{3}\right), 553\left(8.5 \times 10^{3}\right), 582\left(6.2 \times 10^{3}\right), 636$ $\left(4.2 \times 10^{3}\right)$. ${ }^{1} \mathrm{H}-\mathrm{NMR}\left(400 \mathrm{MHz}, \mathrm{D}_{2} \mathrm{O}\right): \delta 1.61(\mathrm{~s}, 36 \mathrm{H}, \mathrm{o}), 3.81(\mathrm{t}, 8 \mathrm{H}$, $\left.{ }^{3} \mathrm{~J}_{\mathrm{HH}}=7.95 \mathrm{~Hz}, \mathrm{~m}\right), 4.13\left(\mathrm{t}, 8 \mathrm{H},{ }^{3} \mathrm{~J}_{\mathrm{HH}}=8.15 \mathrm{~Hz}, \mathrm{l}\right), 4.25(48 \mathrm{H}, \mathrm{CB})$, $4.39(\mathrm{~s}, 8 \mathrm{H}, \mathrm{i}), 4.86(\mathrm{~s}, 8 \mathrm{H}, \mathrm{h}), 5.52(48 \mathrm{H}, \mathrm{CB}), 5.75(48 \mathrm{H}, \mathrm{CB}), 6.62(\mathrm{~s}$, $4 \mathrm{H}, \mathrm{k}), 8.52\left(\mathrm{~d}, 8 \mathrm{H},{ }^{3} \mathrm{~J}_{\mathrm{HH}}=9.9 \mathrm{~Hz}, \mathrm{e}\right), 8.79\left(\mathrm{~d}, 8 \mathrm{H},{ }^{3} \mathrm{~J}_{\mathrm{HH}}=10.1 \mathrm{~Hz}, \mathrm{f}\right)$, 9.09 (s, 8H, a). ${ }^{13} \mathrm{C}-N M R\left(100 \mathrm{MHz}, \mathrm{D}_{2} \mathrm{O}\right): \delta 25.2,40.0,42.5,47.5,51.3$, $51.5,52.5,70.2,120.9,122.5,129.9,130.8,132.7,138.8,138.9,140.1$, $145.1,156.3,156.7$.

ROS Measurement: ${ }^{[16,17]}$ First a $40 \mu \mathrm{m}$ solution of 2,7-dichlorofluorescin (DCFH) was prepared by hydrolyzing dichlorofluorescin diacetate (DCFH-DA) in alkaline media and the resulting solution in sodium phosphate buffer $(\mathrm{pH} 7.4)$ was kept in cold $\left(2{ }^{\circ} \mathrm{C}\right)$ in a dark place until further use. Highly fluorescent DCF (excitation $488 \mathrm{~nm}$, emission at $524 \mathrm{~nm}$, quantum yield: $90 \%$ ) was obtained in the presence of ROS. To investigate the ROS generation ability of [5]rotaxane, first blank measurements were performed as follows: $0.5 \mathrm{~mL}$ of $40 \mu \mathrm{m}$ DCFH was diluted with $1 \mathrm{~mL}$ of water and further excited at $488 \mathrm{~nm}$. The emission intensity at $524 \mathrm{~nm}$ was measured (0 min) then the solution was irradiated under white light $\left(1 \mathrm{~mW} / \mathrm{cm}^{2}\right)$ for 4 minutes, and the emission intensity of blank solution was recorded after every minute.

After blank measurements, $100 \mu \mathrm{L}$ of $5 \mu \mathrm{M}$ [5]rotaxane solution was added to the $0.5 \mathrm{~mL}$ of $40 \mu \mathrm{M}$ DCFH, which was diluted with $1 \mathrm{~mL}$ of water. The same procedure as blank measurements was followed for [5]rotaxane.

Minimum Inhibitory Concentration (MIC Assay): ${ }^{[18]}$ The respective MIC of [5]rotaxane was determined by Broth microdilution method. Hereby, a single colony of $E$. coli on a solid Luria-Bertani (LB) agar plate was transferred to $5.0 \mathrm{~mL}$ of liquid LB culture medium and grown ( $37{ }^{\circ} \mathrm{C}, 200 \mathrm{rpm}, 14$ hours). Bacterial mixture was diluted 2 -fold with pure $\mathrm{LB}$ and initial $\mathrm{OD}_{600}$ value was adjusted to
1.0 and 10 different concentrations were prepared as follows; 0.5, $1.0,1.5,2.0,2.42,2.90,3.40,3.89,4.29$ and $4.74 \mu \mathrm{m} .1 .5 \mathrm{~mL}$-Eppendorf tubes were inoculated with $100 \mu \mathrm{L}$ of bacterial mixture and then $10 \mu \mathrm{L}$ from each concentration was added. For performing the control experiment, equal volume of $10 \mathrm{~mm}$ PBS was used. Both blank and [5]rotaxane containing tubes were exposed to white light for 1 minute with flux of $22 \mathrm{~mW} / \mathrm{cm}^{2}$. The same experiment was also carried out in the dark. After that, eppendorf tubes were placed into incubator (at $37{ }^{\circ} \mathrm{C}, 200 \mathrm{rpm}, 14$ hours). At the end of the incubation period, bacterial mixtures were transferred from eppendorf tubes to 96 -well plate. In microplate reader, $\mathrm{OD}_{600}$ was measured. The results were repeated in triplicate.

Preparation of the Bacterial Solution: A single colony of $E$. coli on a solid LB agar plate was transferred to $5.0 \mathrm{~mL}$ of liquid LB culture medium and grown $\left(37^{\circ} \mathrm{C}, 200 \mathrm{rpm}, 14\right.$ hours). Bacteria were harvested by centrifuging $\left(4{ }^{\circ} \mathrm{C}, 7000 \mathrm{rpm}, 2\right.$ minutes) and washing by phosphate-buffered saline (PBS; $10 \mathrm{~mm}, \mathrm{pH}$ 7.4) three times. The supernatant was discarded and remaining $E$. coli were resuspended in PBS and then diluted so that the $\mathrm{OD}_{600}$ of the bacterial suspension was adjusted to 1.0 .

Investigation of Antibacterial Activity of [5]Rotaxane toward E. coli: Suspension of E. coli $\left(2.0 \mathrm{~mL}, \mathrm{OD}_{600}=1.0\right)$ was diluted 5fold with PBS. According to the results of MIC assay, $3.5 \mu \mathrm{M}$ [5]Rotaxane was added to $2.0 \mathrm{~mL}$ of diluted $E$. coli suspension and the mixture was incubated $\left(37^{\circ} \mathrm{C}, 200 \mathrm{rpm}, 15 \mathrm{~min}\right.$ ) and then irradiated upon white light with a flux of $22 \mathrm{~mW} / \mathrm{cm}^{2}$ for $1 \mathrm{~min}$. Then the bacterial suspension was serially diluted $\left(10^{4}\right.$ fold $)$ in PBS. A $50 \mu \mathrm{L}$ portion of the diluted bacterial mixture was spread on the solid LB agar plate. The colonies formed after 14 hours incubation at $37{ }^{\circ} \mathrm{C}$ were quantified. The same procedure was repeated for the [5]rotaxane incubated with $E$. coli in the dark without exposure to light. Control experiments were carried out with exposure to the light and in the dark by using equal volume of PBS as blank.

Antibacterial activities of nanoparticles toward Gram-positive bacteria (Bacillus subtilis, B. subtilis) were also studied fol- lowing the similar procedure described for $E$. coli.

$\zeta$-Potential Measurements: Suspensions of $E$. coli $\left(100 \mu \mathrm{L}, \mathrm{OD}_{600}=\right.$ $0.95)$ in $500 \mu \mathrm{L}$ of PBS were incubated with $3.5 \mu \mathrm{M}$ of [5]rotaxane $\left(37^{\circ} \mathrm{C}, 200 \mathrm{rpm}, 1 \mathrm{~min}\right)$. After that, they were kept in the dark and exposed to white light for $1 \mathrm{~min}$ with flux of $22 \mathrm{~mW} / \mathrm{cm}^{2}$. The bacteria were harvested by centrifugation at $7000 \mathrm{rpm}$ for $2 \mathrm{~min}$, followed by removal of the supernatant; they were then washed once with water and suspended in $1 \mathrm{~mL}$ of $\mathrm{H}_{2} \mathrm{O}$. The suspensions were kept on ice for $\zeta$-potential measurements, while the measurement itself was performed at $25^{\circ} \mathrm{C}$.

Imaging of Antibacterial Activity by SEM: Prior to the experiment, silica wafers were cut $1 \mathrm{~cm}$ to $1 \mathrm{~cm}$ and incubated for $30 \mathrm{~min}$ with 2-propanol and ethanol respectively in order to remove organic contamination. They were completely dried in air and then placed to 6 well-plate. The bacterial samples for SEM imaging experiments were prepared as follows: Suspensions of E. coli $(100 \mu \mathrm{L}$, $\left.\mathrm{OD}_{600}=1.0\right)$ in $1 \mathrm{~mL}$ of PBS were incubated with [5]rotaxane and (3.5 $\mu \mathrm{M}, 37^{\circ} \mathrm{C}, 200 \mathrm{rpm}, 15 \mathrm{~min}$ ) and then irradiated upon white light with a flux of $22 \mathrm{~mW} / \mathrm{cm}^{2}$ for $1 \mathrm{~min}$, equal volume of PBS was used for control experiment. The same protocol was performed in the dark. $10 \mu \mathrm{L}$ of each sample was taken and fixed onto silica wafers with $2.5 \%$ glutaraldehyde solution in PBS for overnight at $4{ }^{\circ} \mathrm{C}$. Next day, wafers with cells were washed one time with PBS, one time with pure water, one time with $25 \%(\mathrm{v} / \mathrm{v})$ ethanol, one time with $50 \%(\mathrm{v} / \mathrm{v})$ ethanol, one time with $75 \%(\mathrm{v} / \mathrm{v})$ ethanol and one time with pure ethanol for $2 \mathrm{~min}$ each. Following the washing 
steps, the wafers were dried by critical point dryer (CPD) and then coated $5 \mathrm{~nm}$ with Au/Pd alloy. The Samples were examined at $15 \mathrm{kV}$.

\section{In vitro Cell Viability Assay}

Cell Culture: Breast cancer cell line (MCF7) were cultured in Dulbecco's Modified Eagle Medium (DMEM) supplemented with $10 \%$ fatal bovine serum, $1 \%$ penicillin/streptomycin, $0.1 \mathrm{~mm}$ non-essential amino acids and $1 \mathrm{~mm}$ sodium pyruvate at $37{ }^{\circ} \mathrm{C}$ and $5 \% \mathrm{CO}_{2^{-}}$ humidified atmosphere in the dark.

Cytotoxicity: In vitro cytotoxicity of [5]rotaxane was investigated with the MTT cell viability assay. To determine cell viability under dark, $4 \times 10^{3}$ cells were seeded in 96-well tissue culture plates for $24 \mathrm{~h}$, and the next day cells were treated with different concentrations of [5]rotaxane $(0-300 \mu \mathrm{M})$ dissolved in 1X PBS. All dilution series and negative control (without [5]rotaxane) included same volume of PBS and DMEM (Supporting Information Table X), each with three replicates, and incubated for $48 \mathrm{~h}$ at $37^{\circ} \mathrm{C}$. Thiazolyl blue tetrazolium bromide (MTT), membrane-permeable dye (ab146345) was used according to the manufacturer's protocol. Briefly, the medium was removed and replaced with $110 \mu \mathrm{L}$ of DMEM containing [3-(4,5-dimethylthiazol-2-yl)-2,5-diphenyltetrazolium bromide] (MTT, $1.2 \mathrm{~mm}$ ). The mixture was further incubated for $4 \mathrm{~h}$ at $37^{\circ} \mathrm{C}$. The purple formazan product was solubilized in $110 \mu \mathrm{L}$ of SDS- $\mathrm{HCl}$ solution ( $1 \mathrm{~g}$ of SDS in $10 \mathrm{~mL}$ of $10 \mathrm{~mm} \mathrm{HCl}$ ). The plates were incubated overnight at $37^{\circ} \mathrm{C}$, and the absorbance of each microwell was measured at a wavelength of $570 \mathrm{~nm}$ using a microplate reader. To determine the photo-cytotoxicity of [5]rotaxane, the MCF7 cells were seeded and incubated in DMEM as described above. After $24 \mathrm{~h}$, cells were treated with different concentrations of [5]rotaxane $(0-100 \mu \mathrm{M})$. All dilution series and negative control (without [5]rotaxane) had the same volume of PBS and DMEM (Supporting Information Table $\mathrm{X}$ ), each with three replicates and incubated for $24 \mathrm{~h}$ at $37^{\circ} \mathrm{C}$. Irradiation treatment was performed with white light $\left(20 \mathrm{~mW} / \mathrm{cm}^{2}\right)$ from a ZEISS - Cold light source CL 4500 for 5, 10 and $15 \mathrm{~min}$, and then placed in the dark for another $24 \mathrm{~h}$ at $37^{\circ} \mathrm{C}$. The above MTT assay was performed and the absorbance of each well was read at $570 \mathrm{~nm}$.

Statistical Analysis: Differences in MTT relative cell viability (normalized to DMEM control group) were analyzed for each dose in each condition separately using one-way ANOVAs followed by multiple comparisons (Tukey's at $\alpha=0.05$; Graphpad).

\section{Acknowledgments}

We gratefully acknowledge the financial support of the Scientific and Technological Research Council of Turkey (TUBITAK) grant number 215Z035. We would like to thank Prof. Özlen Konu and Dr. Şahika Cıngır Köker for their valuable advice on the biological assays.

\section{Keywords: Rotaxanes · Cucurbituril · Supramolecular} chemistry · Photochemistry · Sensitizers · Porphyrin

[1] a) D. A. Leigh, Angew. Chem. Int. Ed. 2016, 55, 14506-14508; Angew. Chem. 2016, 128, 14722; b) J. F. Stoddart, Angew. Chem. Int. Ed. 2017, 56, 11094-11125; Angew. Chem. 2017, 129, 11244; c) J. P. Sauvage, Angew. Chem. Int. Ed. 2017, 56, 11080-11093; Angew. Chem. 2017, 129, 11228; d) B. L. Feringa, Angew. Chem. Int. Ed. 2017, 56, 11060-11078; Angew. Chem. 2017, 129, 11206.
[2] a) J.-P. Sauvage, C. O. Dietrich-Buchecker (Eds.), Molecular Catenanes, Rotaxanes, and Knots, Wiley-VCH, Weinheim, 1999; b) C. J. Bruns, J. F. Stoddart, The Nature of the Mechanical Bond: From Molecules to Machines, Wiley, 2016

[3] a) A. Coskun, M. Banaszak, R. D. Astumian, J. F. Stoddart, B. A. Grzybowski, Chem. Soc. Rev. 2012, 41, 19-30; b) N. H. Evans, P. D. Beer, Chem. Soc. Rev. 2014, 43, 4658-4683; c) E. A. Neal, S. M. Goldup, Chem. Commun. 2014, 50, 5128-5142; d) S. Erbas-Cakmak, D. A. Leigh, C. T. McTernan, A. L. Nussbaumer, Chem. Rev. 2015, 115, 10081-10206; e) M. Xue, Y. Yang, X. Chi, X. Yan, F. Huang, Chem. Rev. 2015, 115, 7398-7501; f) J. E. M. Lewis, P. D. Beer, S. J. Loeb, S. M. Goldup, Chem. Soc. Rev. 2017, 46, 25772591.

[4] a) Z. Liu, S. K. M. Nalluri, J. F. Stoddart, Chem. Soc. Rev. 2017, 46, 24592478 ; b) J. Murray, K. Kim, T. Ogoshi, W. Yao, B. C. Gibb, Chem. Soc. Rev. 2017, 46, 2479-2496.

[5] a) W. L. Mock, N.-Y. Shih, J. Org. Chem. 1986, 51, 4440; b) W. L. Mock, N.-Y. Shih, J. Am. Chem. Soc. 1988, 110, 4706; c) W. L. Mock, Top. Curr. Chem. 1995, 175, 1.

[6] a) S. Gürbüz, M. Idris, D. Tuncel, Org. Biomol. Chem. 2015, 13, 330-347; b) K. I. Assaf, W. M. Nau, Chem. Soc. Rev. 2015, 44, 394-418; c) D. Shetty, J. K. Khedkar, K. M. Park, K. Kim, Chem. Soc. Rev. 2015, 44, 8747-8761; d) S. J. Barrow, S. Kasera, M. J. Rowland, J. Del Barrio, O. A. Scherman, Chem. Rev. 2015, 115, 12320-12406.

[7] a) D. Tuncel, J. H. G. Steinke, Chem. Commun. 1999, 1509-1510; b) D. Tuncel, J. H. G. Steinke, Chem. Commun. 2001, 253-254; c) D. Tuncel, J. H. G. Steinke, Chem. Commun. 2002, 496-497; d) D. Tuncel, J. H. G. Steinke, Macromolecules 2004, 37, 288-302; e) D. Tuncel, H. B. Tiftik, B. Salih, J. Mater. Chem. 2006, 16, 3291-3296.

[8] D. Tuncel, N. Cındır, U. Koldemir, J. Inclusion Phenom. Macrocyclic Chem. 2006, 55, 373-380.

[9] a) I. Beletskaya, V. S. Tyurin, A. Y. Tsivadze, R. Guilard, C. Stern, Chem. Rev. 2009, 109, 1659-1713; b) C. M. Drain, A. Varotto, I. Radivojevic, Chem. Rev. 2009, 109, 1630-1658; c) N. Aratani, D. Kim, A. Osuka, Acc. Chem. Res. 2009, 42, 1922-1934; d) T. S. Balaban, Acc. Chem. Res. 2005, 38, 612623; e) S. Singh, A. Aggarwal, N. V. S. D. K. Bhupathiraju, G. Arianna, K. Tiwari, C. M. Drain, Chem. Rev. 2015, 115, 10261-10306; f) E. D. Sternberg, D. Dolphin, C. Brückner, Tetrahedron 1998, 54, 4151-4202.

[10] a) D. Phillips, Photochem. Photobiol. Sci. 2010, 9, 1589-1596; b) T. Maisch, Photochem. Photobiol. Sci. 2015, 14, 1518-1526; c) T. Maisch, Mini-Rev. Med. Chem. 2009, 9, 974-983; d) E. C. Ziegelhoffer, T. J. Donohue, Nat. Rev. Microbiol. 2009, 7, 856-863.

[11] A. Fajardo, N. Martinez-Martin, M. Mercadillo, J. C. Galan, B. Ghysels, S. Matthijs, P. Cornelis, L. Wiehlmann, B. Tummler, F. Baquero, J. L. Martinez, PLoS One 2008, 3, e1619.

[12] a) F. Giuntini, F. Bryden, R. Daly, E. M. Scanlanb, R. W. Boyle, Org. Biomol. Chem. 2014, 12, 1203-1206; b) M. H. Staegemann, B. Gitter, J. Dernedde, C. Kuehne, R. Haag, A. Wiehe, Chem. Eur. J. 2017, 23, 3918-3930; c) G. Garcia, D. Naud-Martin, D. Carrez, A. Croisy, P. Maillard, Tetrahedron 2011, 67, 4924-4932; d) O. B. Locos, C. C. Heindl, A. Corral, M. O. Senge, E. M. Scanlan, Eur. J. Org. Chem. 2010, 1026-1028.

[13] a) H. Bai, H. Yuan, C. Nie, B. Wang, F. Lv, L. Liu, S. Wang, Angew. Chem. Int. Ed. 2015, 54, 13208-13213; Angew. Chem. 2015, 127, 13406; b) $\mathrm{H}$. Bai, H. Zhang, R. Hu, H. Chen, F. Lv, L. Liu, S. Wang, Langmuir 2017, 33, 1116-1120; c) H. Bai, H. Chen, R. Hu, M. Li, F. Lv, L. Liu, S. Wang, ACS Appl. Mater. Interfaces 2016, 8, 31550-31557.

[14] a) L. Chen, H. Bai, J. F. Xu, S. Wang, X. Zhang, ACS Appl. Mater. Interfaces 2017, 9, 13950-13957; b) W. Lei, G. Jiang, Q. Zhou, B. Zhang, X. Wang, Phys. Chem. Chem. Phys. 2010, 12, 13255-13260; c) J. Caceres, J. Robinson-Duggon, A. Tapia, C. Paiva, M. Gomez, C. Bohne, D. Fuenteal, Phys. Chem. Chem. Phys. 2017, 19, 2574; d) J. Robinson-Duggon, F. Peŕez-Mora, L. Valverde-Vaśquez, D. Corteś-Arriagada, J. R. De la Fuente, G. Günther, D. Fuentealba, J. Phys. Chem. C 2017, 121, 21782-21789.

[15] a) S. S. Thakare, G. Chakraborty, P. Krishnakumar, A. K. Ray, D. K. Maity, H. Pal, N. Sekar, J. Phys. Chem. B 2016, 120, 11266-11278; b) J. Mohanty, K. Jagtap, A. K. Ray, W. M. Nau, H. Pal, ChemPhysChem 2010, 11, 33333338; c) M. Sayed, F. Biedermann, V. D. Uzunova, K. I. Assaf, A. C. Bhasikuttan, H. Pal, W. M. Nau, J. Mohanty, Chem. Eur. J. 2015, 21, 691-696.

[16] a) K. Liu, Y. Liu, Y. Yao, H. Yuan, S. Wang, Z. Wang, X. Zhang, Angew. Chem. Int. Ed. 2013, 52, 8285-8289; Angew. Chem. 2013, 125, 8443; b) Y. Zhao, Y. Deng, Z. Tang, Q. Jin, J. Ji, Langmuir 2019, 35, 1919-1926; 
c) X. Wang, Y. Liu, Y. Lin, Y. Han, J. Huang, J. Zhou, Y. Yan, ACS Appl. Biol. Mater. 2019, 2, 447-453; d) X. Li, H. Bai, Y. Yang, J. Yoon, S. Wang, X. Zhang, Adv. Mater. 2019, 31, 1805092.

[17] L. Bourre, S. Thibaut, A. Briffaud, N. Rousset, S. Eleouet, Y. Lajat, T.-J. Patrice, J. Photochem. Photobiol. B 2002, 67, 23-31.
[18] G. A. Pankuch, G. Lin, D. B. Hoellman, C. E. Good, M. R. Jacobs, P. C. Appelbaum, Antimicrob. Agents Chemother. 2006, 50, 1727-1730.

Received: February 20, 2019 